\title{
MINERAL AND ORGANOMINERAL FERTIRRIGATION IN RELATION TO QUALITY OF GREENHOUSE CULTIVATED MELON
}

\author{
André Luís Teixeira Fernandes ${ }^{1 *}$; Guilherme Pádua Rodrigues ${ }^{1,2}$; Roberto Testezlaf ${ }^{3}$ \\ ${ }^{1}$ UNIUBE/Instituto de Ciências e Tecnologia do Ambiente - Av. Nenê Sabino, 1801 - CEP: 38055-500 - Uberaba, MG. \\ ${ }^{2}$ FAZU/Faculdade de Agronomia e Zootecnia de Uberaba. \\ ${ }^{3}$ UNICAMP/Faculdade de Engenharia Agrícola, Cidade Universitária "Zeferino Vaz", s/n - Barão Geraldo - CEP: \\ 13083-970, Campinas, SP. \\ *Corresponding author <andre.fernandes@uniube.br>
}

\begin{abstract}
Fertirrigation of melon still presents problems in relation to the type of the fertilizer used, mainly the biofertilizers. This experiment, installed in Uberaba, MG, Brazil, in a plastic module greenhouse of $768 \mathrm{~m}^{2}$, tested treatments consisting of the conventional mineral fertirrigation and the organic fertirrigation, using two frequencies: daily and weekly. The best yields were obtained with daily fertilizer application, with superiority in relation to biofertilizers, with yield of $45.5 \mathrm{t} \mathrm{ha}^{-1}$ of fruit. This value was higher as compared to chemical products, that lead to a yield of $42.4 \mathrm{tha}^{-1}$. The weekly fertigation had lower productivities, and in this case, the biofertilizers also overcame the mineral, on the average $2.0 \mathrm{t} \mathrm{ha}^{-1}$. The best melon soluble solids values were obtained for the daily application of fertilizers, and the best treatment $(P<0.05)$ was the organic daily fertigation, with values of soluble solids content of $13.60^{\circ}$ brix, followed by the daily chemical fertigation, with values of $12.52^{\circ}$. On the average, the amounts of soluble solids in melon were superior to the average found for Brazilian melons. Differences were not verified among the treatments for the variables pulp thickness and fruits $\mathrm{pH}$. Regarding the peel thickness, the application of organic fertilizer sources presented a slight superiority in relation to chemical fertilizer treatments. No differences were verified among treatments in relation to the amount of fruits protein.
\end{abstract}

Key words: Cucumis melo, biofertilizers, fruit quality

\section{FERTIRRIGAÇÃO MINERAL E ORGANOMINERAL NA QUALIDADE DO MELÃO CULTIVADO EM ESTUFA}

\begin{abstract}
RESUMO: A fertilização do melão ainda apresenta incertezas em relação ao tipo de fertilizante utilizado, principalmente quando se utilizam os biofertilizantes. Com o objetivo de monitorar a fertirrigação com fertilizante organomineral comparando-a com a fertirrigação convencional, este experimento avaliou a qualidade final do melão variedade "Orange Flesh", cultivado em estufa plástica. O experimento foi instalado em Uberaba, MG, em condições de ambiente protegido, num módulo de $768 \mathrm{~m}^{2}$, onde foram aplicados os seguintes tratamentos: fertirrigação convencional mineral e fertirrigação com biofertilizante, em duas freqüências: semanal e diária. As melhores produtividades foram obtidas com a aplicação diária de fertilizantes, com superioridade para os produtos organominerais, com produção total de $45,5 \mathrm{t} \mathrm{ha}^{-1}$ de frutos, superior às 42,4 tha ${ }^{-1}$ obtidas com os produtos químicos. A fertirrigação semanal resultou em produtividades inferiores às decorrentes das aplicações diárias, sendo que os produtos organominerais superaram os químicos nesse tipo de aplicação em $2 \mathrm{t} \mathrm{ha}^{-1}$, em média. Os maiores valores de sólidos solúveis totais foram obtidos com a aplicação diária de fertilizantes, em que o melhor tratamento $(P<0,05)$ foi o relativo à fertirrigação orgânica diária, com valores médios de teor de sólidos solúveis de $13,6^{\circ}$ Brix, seguido pelo fertirrigação química diária, com valores médios de teores de sólidos solúveis de $12,52^{\circ}$ Brix. Não foram verificadas diferenças entre os tratamentos para as variáveis espessura de polpa e $\mathrm{pH}$ dos frutos. Com relação à espessura de casca, constatou-se ligeira superioridade dos tratamentos organominerais, quando comparados aos químicos, característica marcante da aplicação de fontes orgânicas na nutrição das culturas. Em termos de teor de proteína dos frutos, não foram verificadas diferenças entre os tratamentos.

Palavras-chave: Cucumis melo, biofertilizante, aspectos qualitativos
\end{abstract}

\section{INTRODUCTION}

In the current context of irrigated agriculture, emphasis has been placed on the called biofertilizers or organomineral fertilizers, produced by inoculating microorganisms into residues of the most diverse categories. The recycling of organic residues, in order to reutilize them as an alternative source for the production of fertilizers is a strategic measure from an environmental standpoint, and is convenient as long as it is economically feasible.

Decree number 86.955, dated 02/18/1982, contains, for the first time in a law, the term organomineral fertilizer, defined in chapter I of the preliminary dispositions as a "fertilizer resulting from a mixture or combination of mineral and organic fertilizers" (Brazil, 1983). With this law, a mixture of fertilizers that agronomists and technicians elsewhere in the world 
recognize as an excellent agricultural input has been made official (Kiehl, 1999).

The literature offers a scarce supply of references relating to qualitative alterations in products harvested after organomineral fertilizers have been used. One of the crops that responds favorably to fertilization with organic fertilizers is melon.

The main attribute of a melon is to be sweet (sugar content) and juicy (juice content), and these characteristics should prevail over visual traits (Gorgatti Netto, 1994). In an experiment conducted in Botucatu, SP, Brazil, Sousa et al. (1998) evaluated the effect of nitrogen $(\mathrm{N})$ and potassium $(\mathrm{K})$ application frequencies via irrigation water on the productivity and quality of melon fruits grown on a sandy-textured soil. The highest commercial and the lowest non-commercial productivities were obtained with more frequent $\mathrm{N}$ and $\mathrm{K}$ applications. In terms of sugars, the values found agree with the ideal range considered by Gorgatti Netto (1994) which classify as marketable melons with soluble solids content mean values above $9^{\circ}$ Brix. The mean soluble solids content of melons in Brazil is $10^{\circ}$ Brix (Pinto et al., 1993), which are values similar to those obtained by Prabhakar et al. (1985) and Srinivas \& Prabhakar (1984) in Indian experiments.

Brito et al. (2000), in an experiment carried out in Petrolina, PE, Brazil, with the melon hybrid AF 682, evaluated the effect of phosphorus sources on yield and quality of melon fruits, and verified that the sources of this nutrient and the application form did not exert influence on fruit mean weight, but phosphoric acid was verified to be superior with regard to total soluble solids content $\left(12.53^{\circ}\right.$ Brix)

In view of the growing environmental awareness in recent years and the shortage of raw materials for chemical fertilizer production, there is an increasing tendency to recycle urban, industrial and agricultural residues, with the objective of controlling environmental pollution and creating new alternative products for agricultural uses, such as organomineral fertilizers. Within this context, we tried to evaluate the application of an organomineral fertilizer (biofertilizer) via irrigation water on greenhouse-grown melons, by comparing it to the conventional fertirrigation with mineral fertilizers, through analysis of qualitative aspects of the product. The effect of dividing the sidedress fertirrigation into installments (both for the biofertilizer and the chemical fertilizers) was also evaluated.

\section{MATERIAL AND METHODS}

The experiment was installed, in Uberaba, MG, Brazil (latitude $19^{\circ} 44^{\prime} 13^{\prime \prime} \mathrm{S}$, longitude 47 $57^{\prime} 27^{\prime \prime} \mathrm{W}$ and altitude $850 \mathrm{~m}$ ), using a Typic Haplustox, with textural contents of: $727 \mathrm{~g} \mathrm{~kg}^{-1}$ sand, $220 \mathrm{~g} \mathrm{~kg}^{-1}$ clay and $53 \mathrm{~g}$ $\mathrm{kg}^{-1}$ silt. The climate in Uberaba is classified as Aw, tropical hot and humid, by the Köppen method, with a winter cold and dry season. The annual precipitation is $1474 \mathrm{~mm}$ and the annual mean temperature is $22.6^{\circ} \mathrm{C}$.

The experiment was carried out under protected environmental conditions, in an experimental module of $12.8 \times 60.0 \mathrm{~m}$, with wooden pillars (pinus) covered by a metallic framework, having a east-west orientation. The module has the following characteristics: internal height: $3.0 \mathrm{~m}$; total height: $4.2 \mathrm{~m}$; side panels: $30 \%$ shade protection; cover: $150 \mathrm{~m}$ plastic, treated against ultraviolet radiation.

The irrigation system consisted of a pump/motor assembly with sand and screen filtering. Selfcompensating drippers were utilized, with a nominal flow rate of $2.3 \mathrm{~L} \mathrm{~h}^{-1}$, inserted into polyethylene tubing (PT) with wall thickness $0.62 \mathrm{~mm}$, internal diameter $15.5 \mathrm{~mm}$, spaced $0.3 \mathrm{~m}$ apart. Spacing was $1.0 \mathrm{~m}$ between rows and $0.3 \mathrm{~m}$ between plants in a row, and each plant was irrigated by one dripper, with experimental plots individualized by valves. A venturi-type injector was utilized to inject both organic and mineral fertilizer solutions, and was calibrated to operate at an injection flow rate of $150 \mathrm{~L} \mathrm{~h}^{-1}$.

The experimental design consisted of a $2 \times 2$ factorial, where factor 1 referred to fertilizer type (two sources $A 1$ and $A 2$, organomineral and mineral, respectively) and factor 2 was the frequency (F1 - daily and F2 - weekly) with four replicates, resulting in four treatments: FOD - fertirrigation with organomineral product (A1) performed daily (F1); FOS - fertirrigation with organomineral product (A1) performed weekly (F2); FQD - fertirrigation with mineral product (A2) on a daily basis (F1); FQS - fertirrigation with mineral product (A2) weekly (F2). Each experimental plot consisted of three planted rows, 45 plants each, plants in the central row being regarded for evaluations (Figure 1).

The biofertilizer, both in solid and liquid forms, was produced at the pilot plant located in Uberaba, MG. The raw materials utilized to produce the organomineral fertilizer were pine wood shavings, urban waste compost and chicken bedding generated in the farm, which were submitted to deodorization, disinfecting and biological transformation processes to produce the solid and the liquid organomineral fertilizers. The production of organomineral fertilizers was carried out in two steps. The first utilized, $700 \mathrm{~kg} \mathrm{Mg}^{-1}$ organic matter (home waste compost, pine wood shavings and avian bedding), 300 $\mathrm{kg} \mathrm{Mg}^{-1}$ phospho-gypsum and a specific biocatalyst, resulting in a product containing $1.5 ; 3.5$ and $1.0 \% \mathrm{~N}$, $\mathrm{P}_{2} \mathrm{O}_{5}$ and $\mathrm{K}_{2} \mathrm{O}$, with $40 \%$ organic matter. In a second step, 20 urea, 25 triple superphosphate, 50 single superphosphate, $30 \mathrm{~kg} \mathrm{Mg}^{-1}$ potassium chloride and a solubilizing catalyst were added to this product which, after material stabilization, gave origin to the organomineral fertilizer.

Fertilization in the organomineral treatments was performed taking into account soil analysis, resulting 2 $\mathrm{kg} \mathrm{m}^{-2}$ of simple solid organomineral fertilizer, which 


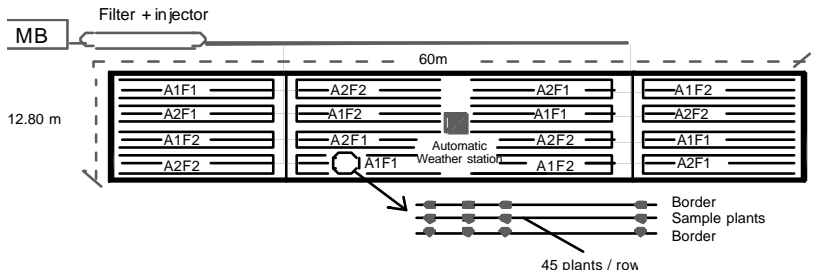

Figure 1 - Representation of the experimental area and location of plots $(\mathrm{A} 1=$ organomineral fertilizer; $\mathrm{A} 2=$ mineral fertilizer; $\mathrm{F} 1$ = daily fertirrigation frequency; $\mathrm{F} 2$ = weekly fertirrigation frequency).

corresponds to a 02-07-04 NPK rate. For treatments involving mineral sources, in addition to the 04-14-08 NPK rate, an application of $300 \mathrm{~g} \mathrm{~m}^{-2}$, organic matter from a conventional source was also utilized, by applying $2 \mathrm{~kg}$ $\mathrm{m}^{-2}$ of rotted barnyard manure enriched with rock phosphate. (1.5; 5.0 and $2.5 \% \quad \mathrm{~N}, \mathrm{P}_{2} \mathrm{O}_{5}$ and $\mathrm{K}_{2} \mathrm{O}$, respectively), thus equalizing the concentrations of nitrogen, phosphorus and potassium with those of the biofertilizer. The solid organomineral fertilizer utilized for fertilization at planting had the following composition: 2.0 $\%$ nitrogen; $7.0 \% \mathrm{P}_{2} \mathrm{O}_{5}$ total; $4.0 \% \mathrm{~K}_{2} \mathrm{O} ; 2.91 \%$ calcium; $6.20 \%$ sulfur; $41.51 \%$ organic matter, $\mathrm{pH}=6.6$ and CEC $=5.5 \mathrm{mmol}_{\mathrm{C}} \mathrm{dm}^{-3}$.

The recommendation of CATI (1999) was followed for the sidedressing, in accordance to the chemical analysis that was made, corresponding to the following nutrient rates, both for chemical and organomineral treatments: a) 30,120 and $60 \mathrm{~kg} \mathrm{ha}^{-1}$ of $\mathrm{N}, \mathrm{P}_{2} \mathrm{O}_{5}$ and $\mathrm{K}_{2} \mathrm{O}$, applied as fertirrigation; b) 1 and $3 \mathrm{~kg}$ $\mathrm{ha}^{-1}$ of $\mathrm{B}$ and $\mathrm{Zn}$, respectively, applied as sprays; c) Molybdenum: $20 \mathrm{~g}(100 \mathrm{~L})^{-1}$ of ammonium molybdate water, in 3 sprays: at the 2 true-leaf stage; at formation of the first branch, and immediately after the $1^{\text {st }}$ flower. The liquid organomineral fertilizer applied as fertirrigation had the following composition: $2.0 \%$ organic $\mathrm{N} ; 7.0 \%$ $\mathrm{P}_{2} \mathrm{O}_{5}$ (phosphorus soluble in NAC - water); $4.0 \% \mathrm{~K}_{2} \mathrm{O}$ (water-soluble potassium); $38.6 \%$ organic matter, $\mathrm{pH}=$ 3.2 and $0.001 \%$ humic acid. The applied chemical fertilizers were of high-solubility, ready-for-use formulated products.

Leaves of thirty plants per plot were removed, before fruiting, and soil samples were collected, one per plot, at three depths ( 0 to $0.20 ; 0.20$ to 0.40 and 0.40 to $0.60 \mathrm{~m}$ ), in order to assess soil fertility at the beginning of the fruiting stage.

The melon hybrid "Orange Flesh - Honey dew" was grown, with a germination rate of $85 \%$ and $99 \%$ purity. Seeding was made directly in the soil, on October 3,2000 . The crop was conducted with plants as single vines, tutored by nylon threads installed on a wire mesh attached to wooden poles, $1.20 \mathrm{~m}$ above soil surface. All shoot and fruit were removed up to the $8^{\text {th }}$ internode, and a single lateral shoot was maintained at every 2 internodes. Only two fruits were maintained per plant to ensure good productivity and a greater number of fruits with a marketable size. The leaves up to the $8^{\text {th }}$ internode were removed 10 days before harvesting in order to improve insolation, increase soil temperature and decrease the evapotranspiration rate.

To provide meteorological monitoring inside the greenhouse, a mini automatic meteorological station, with reduced dimensions $(27.0 \mathrm{~cm}$ in length $\times 11.5 \mathrm{~cm}$ in diameter) was set up in the center of the structure. The station consisted of a data logger with $512 \mathrm{~Kb}$ of nonvolatile memory (PCB), a liquid crystal display (LCD) to show recorded values, an infrared port for communication with a personal computer, a protector against direct solar radiation to prevent the temperature and relative humidity sensors from becoming superheated, and an input connection to the following sensors: air temperature and relative humidity; insolation, precipitation, wind speed and global solar radiation. The evapotranspiration of the crop was estimated by the Penman Monteith method, recommended by FAO, according to Smith (1991).

Soil water content was monitored by means of tensiometer readings installed in all treatments, at depths of $0.20,0.40$ and $0.60 \mathrm{~m}$, in order to ensure that the plots would receive the same water depth of irrigation.

To determine the time necessary for irrigation, calculations were based on the flow rates of the emitter, spacing between emitters, spacing between side rows and an adjustment factor related to the wet irrigation area, since irrigation was localized. The evapotranspiration in the crop $(E T c)$ was estimated by equation 1 :

$E T_{c}=E T_{0} \times K_{m} \times K_{c}$

where: $\mathrm{ET}_{\mathrm{o}}$ - reference evapotranspiration, $\mathrm{mm} \mathrm{d}^{1} ; \mathrm{K}_{\mathrm{c}}$ crop coefficient; $\mathrm{K}_{\mathrm{m}}$ - evapotranspiration adjustment factor for microirrigation, calculated by equation 2 .

$\mathrm{K}_{\mathrm{m}}=\left(\mathrm{A}_{\mathrm{s}}\right)^{1 / 2}$

where: $A_{s}-$ is the shaded area fraction by the crop at noon.

At the first harvest, 80 days after the emergence of the seeds, three fruits were removed per experimental plot, two hours after taken to the laboratory for analysis. For each fruit, the following parameters were analyzed: a) Soluble solids content ( ${ }^{\circ}$ Brix): Readings were made with a Brix refractometer, resolution from 0 to $32^{\circ}$ Brix, with measurements made at a $20^{\circ} \mathrm{C}$, a fact that made measurements somewhat difficult, since the temperature of the samples had to reach room temperature controlled at $20^{\circ} \mathrm{C}$. Readings were taken from a flesh sample of the equatorial region of the fruit, $5 \mathrm{~mm}$ below the central cavity; b) $\mathrm{pH}$ : the measurements were performed with a $\mathrm{pH}$ meter having an operation range from 0 to $14 \mathrm{pH}$, resolution of $0.01 \mathrm{pH}$, precision of $\cong 0.2 \mathrm{pH}$, and operation temperature range of 0 to $50^{\circ} \mathrm{C}$; c) Rind thickness: measurements were taken with a digital caliper rule, with precision $0.01 \mathrm{~mm}$; d) Flesh thickness: also taken with the same digital caliper rule; e) Protein content: made according to the following procedure: A sample of approximately $2 \mathrm{~g}$ taken at the Brix sample extraction 
point was weighed, recording (P1); $10 \mathrm{~mL}$ of hydrogen peroxide $\left(\mathrm{H}_{2} \mathrm{O}_{2}\right)$ were added to $10 \mathrm{~mL}$ of a catalytic mixture of sulfuric acid $\left(\mathrm{H}_{2} \mathrm{SO}_{4}\right)+$ metallic selenium (Se) + copper sulfate $\left(\mathrm{CuSO}_{4}\right)+$ potassium sulfate $\left(\mathrm{K}_{2} \mathrm{SO}_{4}\right)$ in a graduated cylinder; The cylinder was placed in a digestor with four temperature ramps $\left(0-180^{\circ} \mathrm{C} ; 180\right.$ $250^{\circ} \mathrm{C} ; 250-420^{\circ} \mathrm{C}$ and $420-450^{\circ} \mathrm{C}$ ), and exposed for 30 minutes per ramp. The cylinder with the totally digested material, was then placed in a distiller for subsequent distillation, and the solution consumed in the distillation of the nitrogen fraction was collected by an Erlenmeyer flask; Titulation was made with hydrochloric acid $0.2 \mathrm{~mol}$ $\mathrm{L}^{-1}$; Calculations were performed, assuming that $1 \mathrm{mg}$ nitrogen in the ammoniacal $\left(\mathrm{NH}_{3}\right)$ form neutralizes 2.803 $\mathrm{mL}$ of hydrochloric acid $\left(0.2 \mathrm{~mol} \mathrm{~L}^{-1}\right)$ and using a correction factor of 5.95 for the protein/nitrogen ratio.

\section{RESULTS AND DISCUSSION}

Plants of all treatments presented adequate nutrition, with $\mathrm{N}, \mathrm{K}$ and $\mathrm{S}$ values above the values for healthy leaves, and with nutritional rates of $\mathrm{P}, \mathrm{Ca}, \mathrm{Mg}$ and $B$ within the range considered as ideal (Table 1). The nutrient contents in healthy leaves are within ranges varying from 23 to $33 \mathrm{~g} \mathrm{~kg}^{-1}$ of $\mathrm{N}$; 2.8 to $6.2 \mathrm{~g} \mathrm{~kg}^{-1}$ of $\mathrm{P}$; 25.3 to $28.7 \mathrm{~g} \mathrm{~kg}^{-1}$ of $\mathrm{K} ; 25.9$ to $51.4 \mathrm{~g} \mathrm{~kg}^{-1}$ of $\mathrm{Ca} ; 7.9$ to $9.9 \mathrm{~g} \mathrm{~kg}^{-1}$ of Mg; 2.2 to $2.4 \mathrm{~g} \mathrm{~kg}^{-1}$ of $\mathrm{S}$ and 65 to $111 \mathrm{mg}$ $\mathrm{kg}^{-1}$ of B (Katayama, 1993).

Nutritional deficiency symptoms were not verified in plants of any treatments, according to values obtained by Belfort et al. (1986), which verified, in leaves showing deficiency symptoms, values of 11.1 to $22.1 \mathrm{~g} \mathrm{Kg}^{-1}$ of N; 1.2 to $2.3 \mathrm{~g} \mathrm{~kg}^{-1}$ of $\mathrm{P} ; 8.6$ to $17.2 \mathrm{~g} \mathrm{~kg}^{-1}$ of $\mathrm{K} ; 8.5$ to 22.2 $\mathrm{g} \mathrm{kg}^{-1}$ of Ca; 6.0 to $7.1 \mathrm{~g} \mathrm{~kg}^{-1}$ of $\mathrm{Mg} ; 7.1$ to $1.9 \mathrm{~g} \mathrm{~kg}^{-1}$ of $S$ and 55 to $101 \mathrm{mg} \mathrm{kg}^{-1}$ of $\mathrm{B}$. The higher values of $\mathrm{N}$ observed in the leaves could be credited to the lower leaching rate of this element, due to its application via localized irrigation water. Tyler \& Lorenz (1964) obtained greater values for the concentration of $\mathrm{N}$ at the beginning of fruiting, decreasing toward harvest.

Rates of $\mathrm{K}$ and $\mathrm{S}$ higher than those established for healthy leaves were also observed, which could also be attributed to a lower leaching of these elements. Tyler \& Lorenz (1964) verified that the concentration of $\mathrm{K}$ in leaves increased until day 51 , reaching $30.9 \mathrm{~g} \mathrm{~kg}^{-1}$, and then decreased toward the end of the melon cycle. Values found for magnesium are similar, while values for calcium were twice as high as those obtained by Souza (1999). Boron values found by Belfort (1985) were in the order of $55 \mathrm{mg} \mathrm{kg}^{-1}$ during blooming, reaching an acme of $77 \mathrm{mg} \mathrm{kg}^{-1}$, which are values inferior to those found in this experiment, where boron contents ranged between 62 and $120.2 \mathrm{mg} \mathrm{kg}^{-1}$.

The best yields were obtained with daily applications of fertilizers (Table 2), higher than the 42.4 t ha ${ }^{-1}$ obtained with chemical products. Weekly fertirrigation resulted in productivities inferior to those resulting from daily applications, and the organomineral products surpassed the chemical products in this type of application by $2 \mathrm{t} \mathrm{ha}^{-1}$, on the average.

For both the mineral and the organomineral fertilizers, the daily fertirrigation treatments were statistically superior to the weekly fertirrigation treatments (an 8 to $9.2 \mathrm{t} \mathrm{ha}^{-1}$ increase) (Table 2).

No treatment effect was verified for flesh thickness, $\mathrm{pH}$ and \% of proteins, but there were effects for soluble solids content and rind thickness (Table 3).

In relation to $\mathrm{pH}$, no differences were found between the adopted treatments (Table 3 ). Pinto et al. (1994) found higher $\mathrm{pH}$ values (between 6.28 and 6.53), for cultivar Eldorado 300, when irrigation frequencies varied.

For soluble solids content ( ${ }^{\circ}$ Brix), however, which classifies melons as marketable or not, the best treatment $(P<0.05)$ was that associated to daily organic fertirigation, with a mean value of soluble solids content of $13.60^{\circ}$ Brix, followed by the daily mineral fertirrigation, with mean values of $12.52^{\circ}$ Brix. The superiority of the sources, both organomineral and mineral, was due to the daily application of nutrients, with an effect of frequencies at $5 \%$.

No differences were verified between treatments with the application of organomineral or mineral sources, and there was also no interaction effect of sources $x$ fertirrigation frequencies in soluble solids content of melon fruits.

Faria et al. (1994) also obtained high soluble solid content values with the application of natural organic matter, attaining mean values from 12.60 to $13.52^{\circ}$ Brix. By using exclusively mineral sources of nutrients, Buzetti et al. (1993) obtained lower soluble solid content values, in the order of 8.6 to $9.9^{\circ}$ Brix. The poorest treatment, in terms of soluble solids content, was that associated to the weekly application of chemical products (FQS), with mean values around $10^{\circ}$ Brix. The mean soluble solid content

Table 1 - Nutrient contents of melon plant leaves in the fruiting stage.

\begin{tabular}{|c|c|c|c|c|c|c|c|c|c|c|c|c|}
\hline Treatment & $\mathrm{N}$ & $\mathrm{P}$ & $\mathrm{K}$ & $\mathrm{Ca}$ & $\mathrm{Mg}$ & $S$ & $\mathrm{Na}$ & B & $\mathrm{Cu}$ & $\mathrm{Fe}$ & $\mathrm{Mn}$ & $\mathrm{Zn}$ \\
\hline & \multicolumn{6}{|c|}{ - } & \multicolumn{6}{|c|}{ - } \\
\hline Weekly mineral fert. & 51.1 & 4.3 & 26.5 & 49.9 & 7.7 & 12.8 & 63 & 62 & 12 & 190 & 170 & 60 \\
\hline Daily mineral fert. & 38.6 & 3.8 & 39.0 & 54.0 & 8.4 & 12.9 & 72 & 104.7 & 11 & 220 & 160 & 46 \\
\hline Weekly organ. fert. & 40.8 & 3.4 & 27.6 & 47.4 & 8.6 & 10.7 & 78 & 120.2 & 14 & 235 & 135 & 67 \\
\hline Daily organ. fert. & 36.1 & 3.1 & 25.2 & 59.9 & 8.3 & 11.9 & 65 & 89.2 & 12 & 205 & 112 & 55 \\
\hline
\end{tabular}

Scientia Agricola, v.60, n.1, p.149-154, Jan./Mar. 2003 
in the fruits was around 12.04, well above the mean value for melons produced in Brazil (10.2\%) and the soluble solid contents found by Prabhakar et al. (1985).

In a similar work, Pinto et al. (1994) concluded, from an experiment conducted in Petrolina, PE, Brazil, that varying the fertirrigation frequency did not change the soluble solids content in melon plant fruits.

Srinivas \& Prabhakar (1994) verified that applying nitrogen and phosphorus provided significant increments in soluble solids content in melon plant fruits, a fact that explains the superiority, in the present experiment, of treatments with daily fertirrigation frequencies which, according to Table 1, presented smaller $\mathrm{N}$ and $\mathrm{P}$ contents in the leaves, these being elements that were probably destined to take part in the fruiting process.

Treatments consisting of organomineral products developed fruits with greater rind thickness, with an average of $7.78 \mathrm{~mm}$, higher than the thickness in fruits from mineral treatments, which averaged $5.12 \mathrm{~mm}$. Fruits with thinner rinds were obtained with the application of mineral fertilizer sources, as compared to fruits fertilized with organomineral sources, and this superiority was caused specifically by the source of the utilized nutrient (Table 3 ).

The production of fruits with thicker rinds is a remarkable characteristic associated with the use of

Table 2 - Comparison of productivity means, in $\mathrm{Mg} \mathrm{ha}^{-1}$ of fruits, of treatments related to frequency and type of fertilizer.

\begin{tabular}{|c|c|c|}
\hline & \multicolumn{2}{|c|}{ Yield } \\
\hline & \multicolumn{2}{|c|}{-------------- t ha' } \\
\hline Fertirrigation frequency & Organomineral & Mineral \\
\hline Daily & A $45.5 \mathrm{a}$ & A $42.4 \mathrm{a}$ \\
\hline Weekly & B $37.5 \mathrm{~b}$ & B $33.2 \mathrm{~b}$ \\
\hline
\end{tabular}

In each column, means preceded by a common upper-case letter and, in each row, means followed by a common lower-case letter are not different at $5 \%$ by Tukey test. organic sources as nutrients, an interesting fact pertaining to the melon plant fruit in that it increases its useful life in the post-harvest period; however, with regard to flesh thickness, which is the most interesting trait for both the domestic and foreign markets, no differences were verified between treatments.

Also no differences among treatments were detected with respect to protein content in the fruits. Bibliographic references that include protein content determination for melon fruit quality evaluation are scarce.

The equality between treatments can be explained by the nitrogen percentage measured in the leaves, in the beginning of the fruiting stage, similar between treatments (Table 1). Nitrogen constitutes one of the main protein components in fruits.

The organomineral treatments extended the cycle by eight days, totaling 108 days, as compared to a total cycle of 100 days for melon fertirrigated with chemical sources of fertilizers. Faria et al. (1994) attributed this cycle lengthening to the short time available to promote the complete decomposition of the organic matter, thus providing a slower nutrient release in treatments based on fertirrigations with organomineral products.

Most reports dealing with melon production focus on Northeast Brazil, which offers more favorable climatic characteristics for the production of this crop, both quantitatively and qualitatively. However, in the Uberaba, MG region, with the crop grown in a protected environment, it is possible to achieve high productivities of excellent fruit quality.

\section{CONCLUSION}

The utilization of organomineral fertilizers for fertirrigation of melon plants is feasible, since it leads to high productivity with an excellent final quality of fruits, as compared to the utilization of exclusively mineral sources in fertirrigation.

Table 3 - Comparison of qualitative aspects of melon plant fruits from treatments of fertirrigation frequencies and types of fertilizer used.

\begin{tabular}{|c|c|c|c|c|}
\hline \multirow[b]{2}{*}{ Fertirrigation frequency } & & \multicolumn{2}{|c|}{ Fertilizer type } & \multirow[b]{2}{*}{ C.V. (\%) } \\
\hline & & Organomineral & Mineral & \\
\hline \multirow[t]{2}{*}{ Soluble solids content ( ${ }^{\circ}$ Brix $)$} & Weekly & B $12.00 \mathrm{ab}$ & B $10.00 \mathrm{~b}$ & \\
\hline & Daily & A 13.60 a & A $12.52 \mathrm{ab}$ & 12.13 \\
\hline \multirow[t]{2}{*}{ Pulp thickness (mm) } & Weekly & A 25.65 a & A 24.23 a & \\
\hline & Daily & A $25.41 \mathrm{a}$ & A 28.60 a & 12.35 \\
\hline \multirow[t]{2}{*}{ Rind thickness (mm) } & Weekly & A 7.86 a & B 5.94 b & \\
\hline & Daily & A 7.70 a & B $4.30 \mathrm{~b}$ & 27.33 \\
\hline \multirow[t]{2}{*}{$\mathrm{PH}$} & Weekly & A 5.77 a & A 5.91 a & \\
\hline & Daily & A 5.88 a & A 5.78 a & 4.27 \\
\hline \multirow[t]{2}{*}{$\%$ protein } & Weekly & A 0.99 a & A $1.31 \mathrm{a}$ & \\
\hline & Daily & A $1.18 \mathrm{a}$ & A $1.21 \mathrm{a}$ & 47.45 \\
\hline
\end{tabular}

In each column, means preceded by a common upper-case letter and, in each row, means followed by a common lower-case letter are not different at $5 \%$ by Tukey test. 


\section{REFERENCES}

BELFORT, C.C.; HAAG, H.P.; MINAMI, K. Nutrição mineral de hortaliças LXXII. Diagnóstico das carências de macronutrientes e boro em melão (Cucumis melo L.) Anais da ESALQ, v.43, p.365-377, 1986.

BELFORT, C.C. Acumulação de matéria seca e recrutamento de nutrientes em melão (Cucumis melo L. cv. Valenciano Amarelo CAC) cultivado em latossolo vermelho amarelo em Presidente Wenceslau - SP. Piracicaba, 1985. 72p. Tese (Doutorado) - Escola Superior de Agricultura "Luiz de Queiroz", Universidade de São Paulo.

BRASIL. Ministério da Agricultura. Secretaria Nacional de Defesa Agropecuária. Inspeção e fiscalização da produção e do comércio de fertilizantes, corretivos, inoculantes, estimulantes ou biofertilizantes, destinados à agricultura. Brasília: Secretaria de Fiscalização Agropecuária, 1983. 86p.

BRITO, L.T.L.; SOARES, J.M.; de FARIA, M.; COSTA, N.D. Fontes de fósforo aplicadas na cultura do melão via água de irrigação. Revista Brasileira de Engenharia Agrícola e Ambiental, v.4, p.19-22, 2000.

BUZETTI, S.; HERNANDES, F.B.T.; SÁ, M.E.; SUZUKI, M.A. Influência da adubação nitrogenada e potássica na eficiência do uso da água e na qualidade de frutos de melão. Scientia Agricola, v.50, p.419-426, 1993

COORDENADORIA DE ASSISTÉNCIA TÉCNICA INTEGRAL. Manua técnico de culturas. Campinas: CATI, 1999. $1 \mathrm{CD}$.

COSTA, J.E.S. Análise físico-química do melão produzido em condições de casa de vegetação e irrigado pelos sistemas de jato-pulsante e gotejamento. Jaboticabal, 1987. 65p. Monografia (Graduação) - Faculdade de Ciências Agrárias e Veterinárias, Universidade Estadual Paulista "Júlio de Mesquita Filho".

DIAS, N.S.; MEDEIROS, J.F.; SATHLER, N.S. Produção de melão sob duas densidades de plantio, em diferentes tipos e espaçamentos de gotejadores. Revista Brasileira de Engenharia Agrícola e Ambiental, v.4, p. 321-326, 2000.

FARIA, C.M.B. de; PEREIRA, J.R.; POSSIDEO, E.L de. Adubação orgânica e mineral na cultura do melão em um vertissolo do submedio Sao Francisco. Pesquisa Agropecuária Brasileira, v.29, p.191-197, 1994.

GORGATTI NETTO, A. Melão para exportação: procedimentos de colheita e pós-colheita. Brasília: Ministério da Agricultura, do Abastecimento e da Reforma Agrária, Secretaria de Desenvolvimento Rural; EMBRAPA-SPI; 1994. 37p. (Publicações Técnicas FRUPEX, 6)
KATAYAMA M Nutrição e adubação de melão e melancia In: FERREIRA, M.E.; CASTELLANE, P.D.; DA CRUZ, M.C.P. Nutrição e adubação de hortaliças, Piracicaba: Potafos, 1993. p.219-226

KIEHL, E.J. Fertilizantes orgânicos. Piracicaba: Agronômica Ceres, 1985. 492p.

KIEHL, E. J. Fertilizantes organominerais. Piracicaba: O autor, 1999. 146p. MONTEITH, J.L. Evaporation and environment. Symposium of Society on Experimental Biology. London, v.19, p.205-234, 1965

PINTO, J.M.; SOARES, J.M.; CHOUDHURY, E.N.; PEREIRA, J.R. Adubação via água de irrigação na cultura do melão. Pesquisa Agropecuária Brasileira, v.28, p.1263-1268, 1993.

PINTO, J.M.; SOARES, J.M.; PEREIRA, J.R; CHOUDHURY, E.N.; CHOUDHURY, M. M. Efeitos de períodos e de frequências a fertirrigação nitrogenada na produção do melão. Pesquisa Agropecuária Brasileira v.29, n.9, p.1345-1350, 1994

PRABHAKAR, B.S.; SRINIVAS, K.; SHUKLA, V. Yield and quality of muskmelon (cv. Haromadhu) in relation to spacing and fertilization. Progressive Horticultural, v.17, p.51-55, 1985.

SMITH, M. Report on the expert consultation on procedures for revision of FAO guidelines for predictions of crop water requirements. Rome: FAO. 1991, 45p.

SOUSA, V.F. de; COELHO, E.F.; BASTOS, E.A.; FOLEGATTI, M.V.; FRIZZONE, J.A. Doses de nitrogênio e potássio por fertirrigação na produtividade do meloeiro. In: BALBUENA, R.H.; BENEZ, S.H. JORAJURIA, D. Avances en el manejo del suelo y água en la ingenieria rural latinoamericana. La Plata: EUNLP, 1998. p.195-200.

SOUSA, V.F.; COELHO, E.F.; SOUZA, V.A.B. Freqüência de irrigação em meloeiro cultivado em solo arenoso. Pesquisa Agropecuária Brasileira v.34, n.4, p.659-664, 1999

SRINIVAS, K.; PRABHAKAR, B.S. Response of muskmelon (Cucumis melo L.) to varyind lends of spacing and fertilizers. Singapore Journal Primary Industries, v.2, p.36-61, 1984.

TYLER, K.B.; LORENZ, O.A. Nutrient absorption and growth of four muskmelon varieties. Journal of the American Society for Horticultural Science, v.84, p.191-195, 1964.

VIEIRA, G. Índice de maturação para melão (Cucumis meloL.) In: SEMINÁRIO DE OLERICULTURA, 10. Viçosa, 1984. Resumos. Viçosa: UFV, 1984. p.48-67.

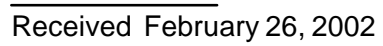

